УДК 311.33:330.5

Лутчин Наталія, кандидат економічних наук, доцент, Львівський національний університет імені Івана Франка, кафедра статистики, м.Львів; ORCID ID: 0000-0002-0727-0842 e-mail: nlutchyn@gmail.com

Саган Діана, магістр спец. «Бізнес-статистика і аналітика», Львівський національний університет імені Івана Франка, https://doi.org/10.29038/2411-4014-2020-01-38-48 м. Львів, e-mail: sagan_diana@ukr.net

\title{
ОЦІНКА НАЦІОНАЛЬНОГО БАГАТСТВА УКРАЇНИ ТА АНАЛІЗ ЧИННИКІВ ЙОГО ЗРОСТАННЯ
}

\begin{abstract}
В статті висвітлюється сучасне розуміння сутності та значення категорії "національне багатство". Розглянуто еволюцію методологічних підходів оцінки національного багатства та визначення його складових. Проаналізовано динаміку національного багатства за допомогою Системи національних рахунків. Визначено тип національної економіки за останні п’ять років 3 врахуванням динаміки національного багатства та Валового внутрішнього продукту. Підтверджена та обгрунтована необхідність включення в склад національного багатства людського капіталу. Здійснена спроба розрахунку людського багатства за методикою Світового банку та статистичною базою Державної служби статистики України. Проведено дисперсійний аналіз складових національного багатства 3 метою оцінки чинників його зростання.
\end{abstract}

Ключові слова:національне багатство, вироблений капітал, природний капітал, людський капітал, дисперсійний аналіз

Лутчин Наталья, кандидат экономических наук, доцент, Львовский национальный университет имени Ивана Франко, кафедра статистики, г.Львов

Саган Диана, магистр спец. «Бизнес-статистика и аналитика», Львовский национальный университет имени Ивана Франко, г.Львов

\section{ОЦЕНКА НАЦИОНАЛЬНОГО БОГАТСТВА УКРАИНЫ И АНАЛИЗ ФАКТОРОВ EГО РОСТА}

В статье освещается современное понимание сущности и значения категории «национальное богатство». Рассмотрена эволюция методологических подходов оценки национального богатства и определения его составляющих. Проанализирована динамика национального богатства с помощью Системы национальных счетов. Определен тип национальной экономики за последние пять лет с учетом динамики национального богатства и Валового внутреннего продукта. Подтверждена и обоснована необходимость включения в состав национального богатства человеческого капитала. Осуществлена попытка расчета человеческого богатства по методике Всемирного банка и статистической базой Государственной службы статистики Украины. Проведен дисперсионный анализ составляющих национального богатства с целью оценки факторов его роста.

Ключевые слова: национальное богатство, произведенный капитал, естественный капитал, человеческий капитал, дисперсионный анализ. 


\section{Lutchyn Nataliya, \\ PhD in Economics, Associate Professor, Lviv Ivan Franko National University, Department of Statistics, Lviv}

Sagan Diana,

master special "Business statistics and analytics", Lviv Ivan Franko National University, Lviv

\section{ASSESSMENT OF THE NATIONAL WEALTH OF UKRAINE AND ANALYSIS OF ITS GROWTH FACTORS}

The study of the category of National Wealth is necessary because the wealth of the nation is an important indicator of the economic power and potential of the country. In this regard, the study of national wealth has become particularly popular in recent years in countries with transformational economies, where the absence of market relations over a long time has led to an unbiased valuation of property and their too low cost in privatization.

Today, there are no similar views on the definition of the essence of National Wealth. The ambiguity of interpretations of the term «National Wealth» and his assessment methods may indicate a lack of scientific research in this field.

The purpose of the work is to study the concept, structure, methods of assessment, and most importantly - ways to increase the national wealth of Ukraine. After all, determining the composition and state of national wealth of the country reveals the main priorities of development, namely: structural policy, privatization policy, investment policy, etc.

The article highlights the modern understanding of the essence and meaning of the category "national wealth". The evolution of methodological approaches to assessing national wealth and defining its components are considered. The dynamics of national wealth were analyzed using the National Accounts System. The type of national economy over the last five years has been determined taking into account the dynamics of National Wealth and Gross Domestic Product. The necessity for inclusion to the national wealth the human capital was confirmed and justified. An attempt has been made to calculate human wealth according to the World Bank methodology and the statistical base of the State Statistics Service of Ukraine. A variance analysis of the components of national wealth has been carried out in order to assess its growth factors.

The results of the analysis conclude that the priority direction for the growth of national wealth in Ukraine is investment in human capital.

Keywords: national wealth, produced capital, natural capital, human capital, analysis of variance

Постановка наукової проблеми та її значення. В умовах посилення глобалізаційних процесів збільшується роль такого макроекономічного показника, як національне багатство, яке відіграє важливу роль в процесах сталого розвитку. Значимість національного багатства полягає в тому, що воно $€$ передумовою наступних циклів розширеного відтворення національної економіки. Загострення сучасних екологічних, економічних, демографічних та ресурсо-енергетичних проблем вимагає детальнішого дослідження змін у системі національного багатства кожної країни. Дослідження категорії національного багатства необхідне тому, що багатство нації є важливим показником економічної могутності і потенціалу країни. Зростання частки національного багатства кожної країни в сукупному багатстві свідчитиме про підвищення рівня розвитку країни, іiі можливостей у впливі на ситуацію на світових ринках при прийнятті міжнародних економічних й політичних рішень. У зв'язку з цим, дослідження національного багатства набуває особливої популярності в останні роки в країнах 3 трансформаційною економікою, де відсутність ринкових відносин протягом тривалого часу призвела до необ'єктивної оцінки об'єктів власності й до їх надто невисокої ціни при здійсненні приватизації [1].

Аналіз досліджень проблеми. Підгрунтя сучасного розуміння сутності та значення категорії "національне багатство" було закладене К.Марксом та класиками політичної економії - У.Петті, А.Смітом, Д.Рікардо. Історично ж науково досліджувати національне багатство першими почали меркантилісти (Ч.Давенант, Т.Ман, В.Стаффорд - в Англії, А.Монкретьян - у Франції), та фізіократи (Ф.Кене, В.Мірабо, А.Тюрго та ін.) [2]. Першою в світовій історії економічною оцінкою 
національного багатства країни були розрахунки англійського економіста У.Петті, який розділив багатство на складові на основі видів майна й розрахував вартість його елементів, капіталізувавши доход від них, виходячи з різних строків окупності, тобто враховуючи характер їхнього відтворення $[2$, c. 25$]$.

За останні десять років спроба реальної оцінки величини національного багатства України представлена в наукових дослідженнях О.Ляховець[1], І.Бобух [2], М. Квак [3], С. Шумської [4], С.Степаненко [5] та монографії С.Пирожкової та М.Хвесика [6]. Проте сьогодні немає однакових поглядів на визначення сутності національного багатства. Неоднозначність тлумачень поняття «національне багатство», так і методів його оцінки може свідчити про недостатність наукових розробок в цій галузі. У розрахунках, здійснених у 2006 р. фахівцями Світового банку, серед яких К.Гамільтон, Г.Рута, К.Болт, А.Маркандья, С.Педросо-Галінато, Р.Сильва, М.Саид Ордоубади, Г.Ланг, Л.Таджибаєва [7] , національне багатство було обчислене як поточна вартість майбутнього споживання. Оцінки запасів виробленого капіталу були отримані на основі моделі безперервної інвентаризації [2]. За методологію Всесвітнього банку, яка була оприлюднена 30 січня 2018 року, до складу національного багатства додатково був включений людський капітал, що на нашу думку $€$ цілком логічно. Адже високоосвічений, потенційно здоровий та висококваліфікований людський капітал однозначно має бути складовою національного багатства. Це значно відрізняється від минулих оцінок, коли загальне багатство оцінювалось іншим шляхом, припускаючи, що споживання $\epsilon$ доходом від загального багатства.

За попередніми підрахунками, вироблений капітал, природний капітал та чисті іноземні активи розраховувались безпосередньо, а потім їх віднімали від загального майна ,щоб отримати залишок. Незрозумілий залишок, який називався "нематеріальним капіталом", в значній мірі був приписаний людському капіталу. Тепер, із можливістю прямого виміру людського капіталу, загальне багатство можна оцінити як суму кожної категорії активів.

Мета та завдання дослідження - це вивчення поняття та структури національного багатства, методів оцінки, а головне - шляхів збільшення національного багатства України. Адже визначення складу і стану національного багатства країни дозволяє виявити основні пріоритети розвитку, а саме: формувати й коригувати структурну політику, інвестиційну політику, політику ресурсозбереження тощо.

Виклад основного матеріалу i обгрунтування отриманих результатів дослідження. Розрахунок такого важливого макроекономічного показника, як національне багатство, може бути здійснена на основі системи національних рахунків (СНР).Збільшення багатства безпосередньо залежить від обсягів виробництва за визначений часовий проміжок.

Для розрахунку національного багатства в СНР складається баланс активів і пасивів, що завершує послідовність рахунків у системі. Баланс активів і пасивів може складатися для інституційної одиниці, сектору, галузі й внутрішньої економіки загалом. Для кожного сектору баланс показує фінансові активи та фінансові зобов'язання, прийняті сектором із метою залучення фінансових ресурсів[8]. Ця інформація важлива для виявлення активів секторів, що здійснюють чисте запозичення та використовують для фінансування свого дефіциту, а також активів секторів, що здійснюють чисте кредитування і використовують для розміщення своїх надлишкових коштів.

У балансі відображаються всі види економічних активів. За аналогією 3 рахунками нагромадження, активи відображаються в лівій частині балансу, а пасиви й чиста вартість капіталу в правій. Балансуючою статтею є чиста вартість власного капіталу, що розраховується як різниця між вартістю всіх активів і вартістю пасивів. Чиста вартість власного капіталу в економіці загалом становить національне багатство країни, обсяг якого розраховується у вартісному виразі в ринкових цінах, які діють на момент оцінки активів [4].

Якщо скористатись експериментальними балансами нефінансових і фінансових активів та пасивів за 2017 р., які вперше були представлені на сайті Державної служби статистики України в 2011 р. (табл. 1 і 2), то можна отримати оцінку національного багатства. 
Дані експериментального балансу фінансових активів і пасивів України за 2017 р.,млн грн

\begin{tabular}{|l|l|l|}
\hline \multicolumn{1}{|c|}{ Активи } & \multicolumn{1}{|c|}{ Показник } & \multicolumn{1}{c|}{ Пасиви } \\
\hline 12774966 & Початковий баланс & 13665805 \\
\hline 887417 & Фінансовий рахунок & 938951 \\
\hline 320042 & Рахунки інших змін у активах & 53065 \\
\hline 13982425 & Заключний баланс & 14657821 \\
\hline
\end{tabular}

Джерело: сформовано автором за даними [8]

Таблиия 2

Експериментальний баланс нефінансових активів України за 2017 р.,млн грн.

\begin{tabular}{|c|c|c|c|c|}
\hline Нефінансові активи & $\begin{array}{c}\text { Початковий } \\
\text { баланс } \\
\end{array}$ & $\begin{array}{l}\text { Рахунок } \\
\text { капіталу }\end{array}$ & $\begin{array}{c}\text { Рахунки інших змін } \\
\text { в активах }\end{array}$ & $\begin{array}{c}\text { Заключний } \\
\text { баланс }\end{array}$ \\
\hline Усього & 6495916 & 202646 & 790475 & 7489037 \\
\hline Основні засоби & 5370758 & 77916 & 647876 & 6096550 \\
\hline $\begin{array}{l}3 \quad \text { них: продукти } \\
\text { інтелектуальної } \\
\text { власності }\end{array}$ & 49480 & -827 & 3946 & 52599 \\
\hline $\begin{array}{l}\text { Матеріальні оборотні } \\
\text { кошти }\end{array}$ & 1125158 & 124730 & 142599 & 1392487 \\
\hline
\end{tabular}

Джерело: сформовано автором за даними [8]

(Без урахування цінностей. Без урахування житлових будівель у зв'язку з відсутністю повної інформації щодо якісного їх складу та ринкової ціни.)

Нижче наведена динаміка чистої вартості власного капіталу (національного багатства) за 20132017 роки у фактичних та порівнянних цінах ( в цінах 2013 року)

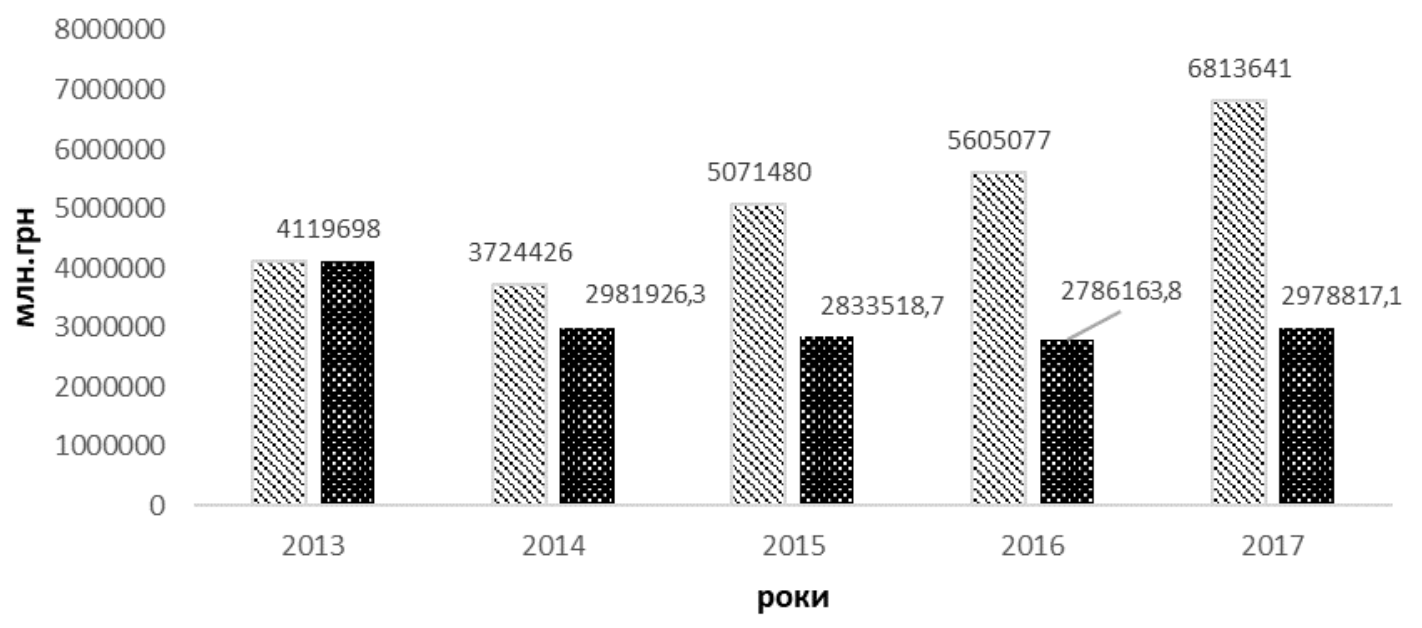

$$
\begin{aligned}
& \text { × Чиста вартість власного капіталу в фактичних цінах } \\
& \text { Чиста вартість власного капіталу в порівнянних цінах }
\end{aligned}
$$

Рис.1 . Динаміка чистої вартості власного капіталу (національного багатства) за 2013-2017 рр в фактичних та порівнянних цінах., млн грн.

Джерело: сформовано автором за даними [8]

Перш за все, бачимо значне відхилення між показниками чистої вартості власного капіталу України в фактичних цінах та в цінах 2013 року, що свідчить про інфляційні процеси в країні в зв'язку з ростом цін на товари та послуги з одночасним скорочення обсягів виробництва, що не 
могло не позначитись на зниженні купівельної спроможності населення та його добробуті. Але, звісно, першопричиною цих процесів стала політична ситуація в країні та значна втрата територій. Адже різке зниження чистої вартості власного капіталу спостерігаємо саме у 2014 році з подальшою негативною тенденцією протягом 2015-2016 років. Це говорить про складну політичну ситуацію в країні через воєнні дії на Сході України. І тільки в 2017 році, коли економіка країни дещо оговталась від втрат, тенденція змінилась до зростання.

Загалом варто зауважити, що реформи в масштабі країни (економічні, політичні тощо) мають безпосередній вплив на динаміку багатства нації. Неможливо заперечити зв'язок національного багатства й темпів розвитку економіки. У цьому контексті доречно згадати пропозицію В.К. Фальцмана щодо застосування двоїстої оцінки економічного зростання, яка дає змогу виміряти показники “потоків продукції національного доходу i, крім того, запасів майна, природних, людських ресурсів та інноваційного потенціалу, тобто елементів багатства".Така оцінка допомагає виділити 4 типи економічної динаміки [4]:

1) зростання національного продукту та багатства;

2) збільшення національного продукту за рахунок зменшення національного багатства;

3) скорочення національного продукту за приросту багатства;

4) зменшення як продукту, так і багатства.

Говорячи про економічну динаміку України, то вона змінювалась протягом $2013-2017$ років (рис.2).

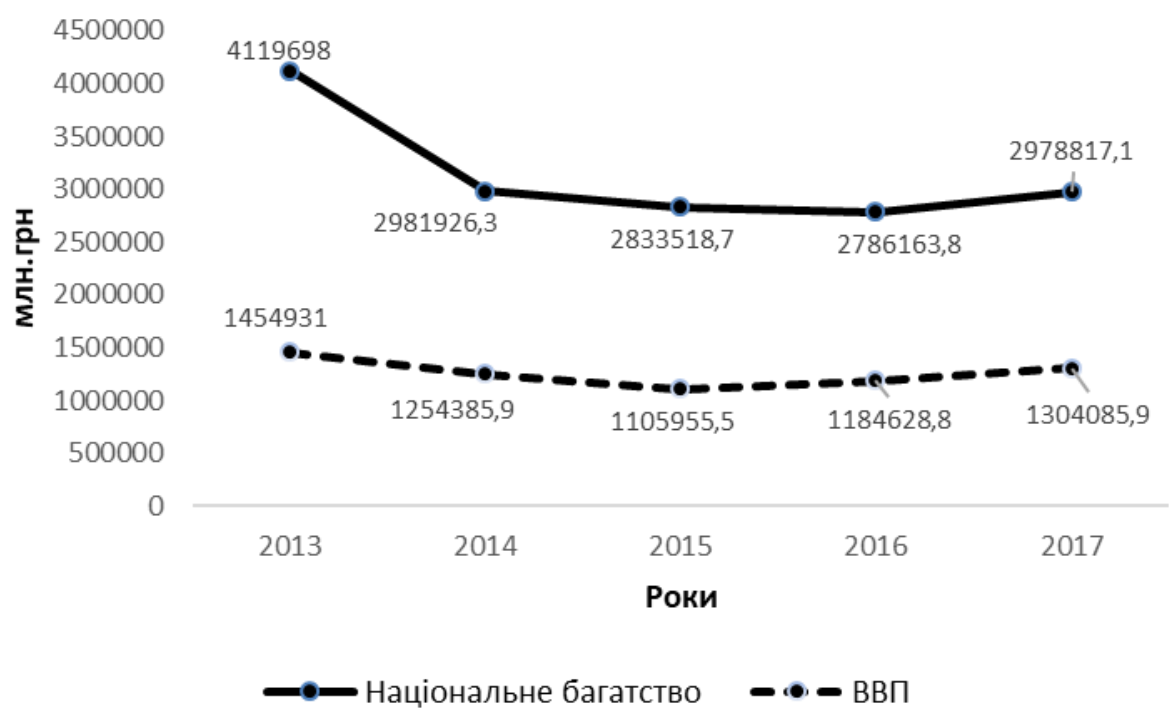

Рис. 2. Динаміка НБ та ВВП України в цінах 2013 року протягом 2013-2017 рр., млн грн. Джерело: побудовано автором за даними [8]

В 2014 та 2015 роках спостерігалась динаміка четвертого типу, тобто зменшення як продукту, так і багатства. Очевидно, цей процес мав політичне підгрунтя. Але вже в 2016 році динаміка набула другого типу, тобто національний продукт почав збільшуватись, коли національне багатство продовжило зменшуватись. Це пояснюється втратою важливих елементів національного багатства. I аж в 2017 році динаміка знову набула першого типу, тобто почалось зростання і національного продукту і багатства, що говорить про певні позитивні тенденції розвитоку економіки.

Недоліками методології розрахунків національного багатства України в рамках показників СНР $\epsilon$ недооцінка природного капіталу та відсутність оцінок людського капіталу. На сучасному етапі, коли на перше місце серед факторів економічного зростання виходить людський капітал, неврахування останнього істотно змінює результати, занижує потенціал розвитку.

Загальний людський капітал (за методологією Світового банку) обчислюється як дисконтована вартість доходів (вартість майбутніх потоків доходів, оцінена в теперішніх умовах) за життя двох підгруп населення: осіб віком від 25 до 65 років (передбачається, що вони закінчили навчання) та 
осіб віком 15-24 років, які мають певну ймовірність навчатися в школі. Такі показники, як річний заробіток (за віком, статтю, рівнем освіти) та освітні досягнення (за віком, статтю) беруть 3 Міжнародної бази розподілу доходів (I2D2). Роки навчання в школі беруть 3 оновленої оцінки, похідної від I2D2. Населення та рівень смертності (за віком, статтю) беруть 3 даних Відділу Організації Об'єднаних Націй в області народонаселення (United Nations Population Division) та частку праці у ВВП (зайняті та самозайняті) з національних рахунків ООН [7].

На рисунку 3 наведена оцінка національного багатства України за даними Всесвітнього банку протягом 1995-2014 pр.

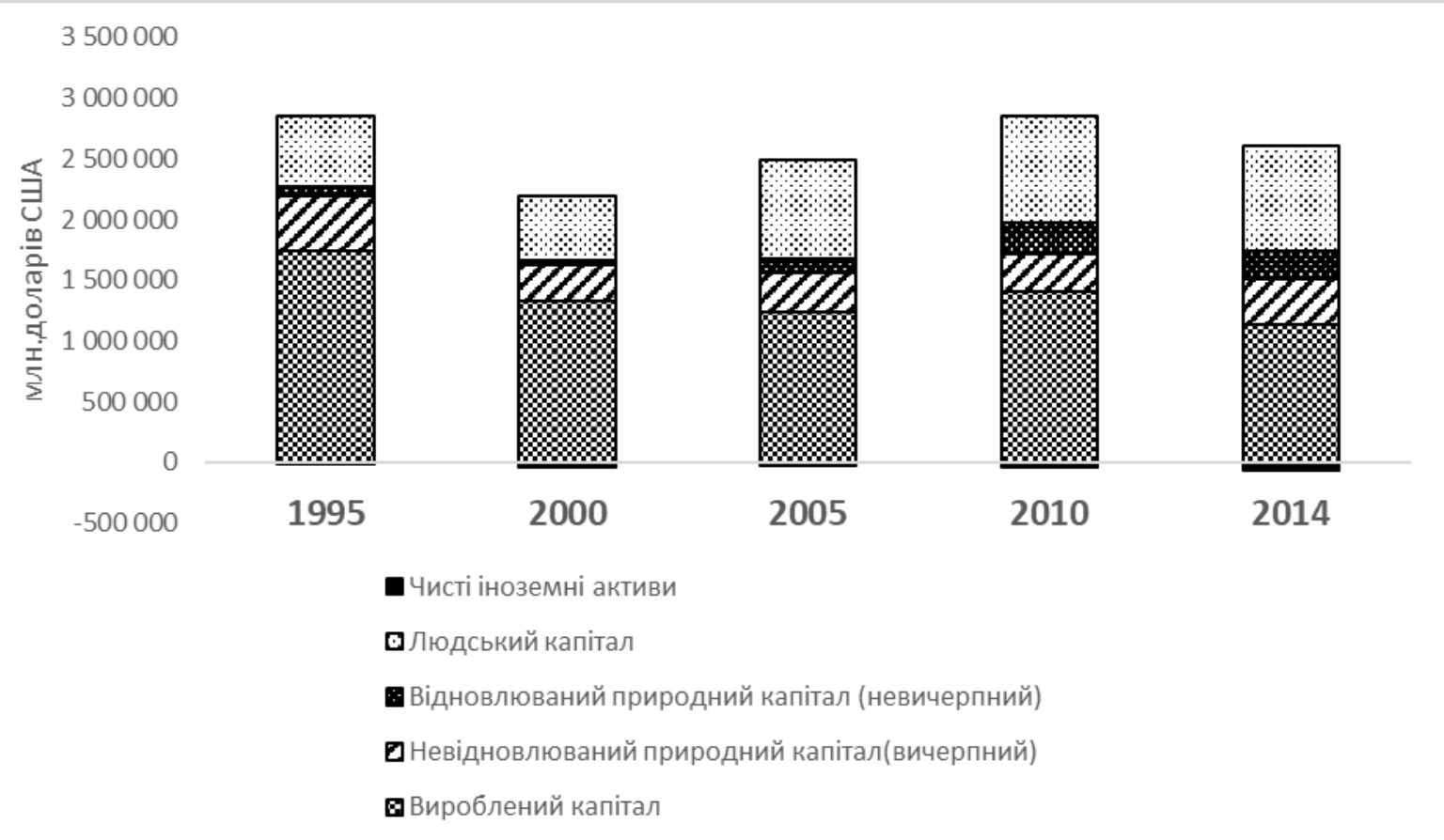

Рис.3. Динаміка складових наџіонального багатства України протягом 1995- 2014 рр, млн..доларів США.

Джерело: побудовано автором за даними [9]

Як видно 3 рис. 3, після певного зростання, відбулося зменшення національного багатства України у 2014 році. Дана ситуація очевидна і пов'язана з втратами у зв'язку з анексією Криму та формування непідконтрольних територій в результаті військових дій на сході України.

В роботі здійснена спроба розрахунку людського капіталу в складі національного багатства за методикою Світового банку та даними Державної служби статистики України. Складові для такого розрахунку наведені в таблиці 3 .

Табличя 3

Динаміка складових людського капіталу за 2014-2018 роки

\begin{tabular}{|l|l|l|l|l|c|}
\hline \multicolumn{1}{|c|}{ Показники } & \multicolumn{1}{|c|}{2014} & \multicolumn{1}{c|}{2015} & \multicolumn{1}{c|}{2016} & \multicolumn{1}{c|}{2017} & \multicolumn{1}{c|}{2018} \\
\hline Наявний дохід у розрахунку на одну особу, грн. & 21442,8 & 17768,9 & 18431,6 & 20665,6 & 23057,1 \\
\hline Чисельність населення, тис. осіб & 45426,2 & 42929,3 & 42760,5 & 42584,5 & 42386,4 \\
\hline Зайняте населення у віці 15-70 років,тис. осіб & 18073,3 & 16443,2 & 16276,9 & 16156,4 & 16360,9 \\
\hline $\begin{array}{l}\text { Кількість студентів закладів вищої освіти у у } \\
\text { розрахунку на 10000 населення }\end{array}$ & 393 & 375 & 373 & 363 & 361 \\
\hline
\end{tabular}

Джерело: складено автором за даними [8]

Загальний людський капітал обчислений як вартість доходів (вартість майбутніх потоків доходів, оцінених в сучасних умовах, тобто станом на 2018 рік) за життя осіб у віці 15-70 років. 
3 урахуванням міжнародних підходів, зайнятими економічною діяльністю (зайняте населення) вважають осіб віком 15-70 років, які впродовж обстежуваного тижня:

- працювали хоча б 1 годину:

$>$ за наймом за винагороду в грошовому чи натуральному вигляді, індивідуально (самостійно), у окремих громадян або на власному (сімейному) підприємстві;

працювали безкоштовно на підприємстві, у власній справі, що належить будь-кому з членів домогосподарства, або в особистому селянському господарстві з метою реалізації продукції, виробленої внаслідок цієї діяльності;

- особи, які були тимчасово відсутні на роботі, тобто формально мали робоче місце, власне підприємство (власну справу), але не працювали впродовж обстежуваного періоду з незалежних від них особисто обставин.

Обрахуємо скільки ще років зайняте населення у віці 15-70 років буде працювати а, отже, приносити дохід.

$$
\text { Years }=\sum_{n=15}^{n=70}(70-n)=1540 \text { (років) }
$$

Відсоток смертності у віці $15-70$ років складає $18 \%$, тому і кількість років зменшимо на $18 \%$ та отримаємо 1262,8. Даний показник необхідно помножити на кількість зайнятого населення у віці 1570 років та на наявний дохід у розрахунку на одну особу за 2018 рік. Щоб порівняти його 3 показниками людського капіталу, які обчислює Світовий банк, конвертуємо гривні в мільйони доларів США згідно середнього курсу за 2018 рік, що становив 26,6гривень за долар США.

Обрахований показник людського багатства станом на 2018 рік склав 17897307,8 млн. дол. США, а за звітом Всесвітнього банку, станом на 2014 рік він складав 857998,1 млн. дол. США. Отже, людський капітал України після суттєвого зменшення у 2014 році частково зріс за ці 4 роки. Звісно, наша оцінка $\epsilon$ недостатньо точною з врахуванням відсутності даних щодо кількості років навчання , тому можна допустити, що цей показник може бути дещо завищеним. Проте, на нашу думку, зростання людського капіталу все ж таки відбулось, хоча й не таке велике.

Проаналізуємо, яким є розподіл складових національного багатства і чи є в цьому певна закономірність 3 використанням дисперсійного аналізу. За допомогою дисперсійного аналізу досліджують вплив однієї або декількох незалежних змінних (факторів) на одну залежну змінну (одномірний аналіз) або на декілька залежних змінних (багатомірний аналіз). Дисперсійний однофакторний аналіз використовується у дослідженнях зміни результативної ознаки під впливом зміни умов або градацій фактора. При проведенні дисперсійного аналізу необхідно перевірити нормальність розподілу досліджуваної випадкової величини і відсутність відмінності дисперсій сукупностей [10].

Аналіз був здійснений на основі даних Світового банку для 16 країн світу.

Таблиия 4

Аналітичне групування країн Європи за складовими національного багатства, дол.США

\begin{tabular}{|l|c|c|c|}
\hline \multirow{2}{*}{ Країна } & \multicolumn{3}{|c|}{ Національне багатство (на 1 особу), доларів США } \\
\cline { 2 - 4 } & Вироблений капітал & Природний капітал & Людський капітал \\
\hline Бельгія & 211872,7 & 5012,8 & 404997,3 \\
\hline Франція & 223830,1 & 11108,6 & 415850,9 \\
\hline Велика Британія & 193455,7 & 7592,0 & 457222,7 \\
\hline Іспанія & 142820,5 & 10298,2 & 215592,8 \\
\hline Італія & 188054,7 & 8619,3 & 241349,6 \\
\hline Мальта & 75153,5 & 1654,8 & 218865,3 \\
\hline
\end{tabular}


РОЗДІЛ ІІ. Економіка й управління національним господарством. 1, 2020

\begin{tabular}{|l|c|c|c|}
\hline Греція & 134895,0 & 12546,2 & 105662,8 \\
\hline Німеччина & 236890,7 & 7700,6 & 467668,1 \\
\hline Нідерланди & 234414,6 & 9528,3 & 516543,5 \\
\hline Естонія & 91645,8 & 20092,8 & 155040,7 \\
\hline Україна & 25170,5 & 13345,2 & 18952,1 \\
\hline Литва & 63254,2 & 12757,7 & 100081,4 \\
\hline Болгарія & 23185,5 & 16683,5 & 47592,8 \\
\hline Угорщина & 65561,0 & 6622,6 & 102557,4 \\
\hline Молдова & 14212,8 & 4897,5 & 17852,4 \\
\hline Білорусія & 33388,2 & 21881,7 & 49003,6 \\
\hline Австрія & 256743,9 & 16265,5 & 421845,7 \\
\hline Португалія & 117409,3 & 9189,4 & 172162,5 \\
\hline Польща & 285791,5 & 27890,2 & 576520,6 \\
\hline
\end{tabular}

Джерело: Складено автором за даними [9]

Першим кроком необхідно сформулювати гіпотези, за допомогою яких був здійснений дисперсійний однофакторний аналіз:

$H_{0}$ : Немає закономірної різниці в середніх показниках складових національного багатства (вироблений капітал, природний капітал, людський капітал), для різних країн вони мають різні частки в загальному показнику багатства.

$H_{1}$ : Існує закономірна різниця в тому, які частки в загальному показнику національного багатства мають його складові (вироблений капітал, природний капітал, людський капітал).

В табл.5 наведені результати для згенерованих вибірок.

Таблиия 5

Підсумки однофакторного дисперсійного аналізу

\begin{tabular}{|l|l|l|l|l|}
\hline \multicolumn{1}{|c|}{ Групи } & Рахунок & Сума & \multicolumn{1}{|c|}{ Середнє } & \multicolumn{1}{|c|}{ Дисперсія } \\
\hline Вироблений капітал & 19 & 2617750,199 & 137776,3263 & 7943931559 \\
\hline Природній капітал & 19 & 223686,8122 & 11772,99011 & 42206876,89 \\
\hline Людський капітал & 19 & 4705362,243 & 247650,6444 & 34440808577 \\
\hline
\end{tabular}

Джерело: розраховано автором за даними таблиці 4.

В таблиці 6 наведені результати дисперсійного аналізу

Таблиия 6

Результати дисперсійного аналізу

\begin{tabular}{|c|c|c|c|c|c|c|}
\hline \multicolumn{7}{|c|}{ Дисперсійний аналіз } \\
\hline $\begin{array}{c}\text { Джерело } \\
\text { варіачій }\end{array}$ & $S S$ & $d f$ & $M S$ & $F$ & $\begin{array}{c}P- \\
\text { значення }\end{array}$ & F критичне \\
\hline Між групами & 792596491332,4 & 2 & 264198830444,1 & 24,7722652 & $4,05 \mathrm{E}-11$ & 2,731807 \\
\hline В межах груп & 767887621145,1 & 54 & 10665105849,2 & & & \\
\hline Всього & 1560484112477 & 56 & & & & \\
\hline
\end{tabular}

Джерело: розраховано автором за даними таблиці 4.

Перевіримо виявлений зв'язок на щільність за допомогою $\eta^{2}$ 


$$
\eta^{2}=\frac{\text { SSB }}{\text { SST }}=\frac{792596491332,4}{1560484112477_{a} 5}=0,5079
$$

Для одержання висновків про практичну значимість кореляційного відношення використовують також шкалу Чедока (табл. 7).

Таблиия 7

Шкала Чедока

\begin{tabular}{|l|l|l|l|l|l|l|}
\hline Рівень щільності зв'язку & $0,1-0,3$ & $0,3-0,5$ & $0,5-0,7$ & $0,7-0,9$ & $0,9-1,0$ \\
\hline $\begin{array}{l}\text { Характеристика щільності } \\
\text { мовна, якісна }\end{array}$ & зв’язку, слабкий & помірний & середній & високий & $\begin{array}{l}\text { дуже } \\
\text { високий }\end{array}$ \\
\hline
\end{tabular}

Джерело: побудовано за [10].

В нашому випадку із значенням 0,5079 можемо стверджувати що наявний середній зв'язок.

Перевіримо істотність зв'язку за допомогою F-критерію Фішера:

$$
F=\frac{\frac{S S B}{k-1}}{\frac{S S W}{n-k}}=24,7722
$$

Для перевірки істотності визначимо критичне значення F- критерію для кількості ступенів свободи $\mathrm{df}=\mathrm{k}-1=2 \mathrm{i} \mathrm{df}=\mathrm{n}-\mathrm{k}=54$

3 табульованих значень Fкрит. $=2,731807$

Отже, оскільки Гфакт. > Ғкрит., відхиляємо нульову гіпотезу і з ймовірністю 95\% стверджуємо, що середні значення різні, тобто існують суттєві відмінності у середніх значеннях складових національного багатства.

Таким чином можемо стверджувати про статистичну значущість відмінностей між середніми випадкових величин у групах, які відповідають різним складовим національного багатства. 3 даних таблиці 8 видно, що найбільший вклад в національне багатство робить людський капітал.

Таблиия 8

Частка складових національного багатства, 2014 рік

\begin{tabular}{|l|c|c|c|}
\hline \multirow{2}{*}{ Країна } & \multicolumn{3}{|c|}{ Структра національного багатства,\% } \\
\cline { 1 - 4 } & $\begin{array}{c}\text { Вироблений } \\
\text { капітал }\end{array}$ & $\begin{array}{c}\text { Природний } \\
\text { капітал }\end{array}$ & Людський капітал \\
\hline Бельгія & 33 & 1 & 63 \\
\hline Франція & 35 & 2 & 65 \\
\hline Велика Британія & 30 & 1 & 71 \\
\hline Іспанія & 42 & 3 & 63 \\
\hline Італія & 44 & 2 & 56 \\
\hline Мальта & 25 & 1 & 72 \\
\hline Греція & 59 & 6 & 64 \\
\hline Німеччина & 32 & 1 & 65 \\
\hline Нідерланди & 30 & 1 & 34 \\
\hline Естонія & 35 & 8 & 59 \\
\hline Україна & 45 & 24 & 60 \\
\hline Литва & 37 & 8 & \\
\hline
\end{tabular}


РОЗДІЛ ІІ. Економіка й управління національним господарством. 1, 2020

\begin{tabular}{|l|c|c|c|}
\hline Болгарія & 28 & 20 & 58 \\
\hline Угорщина & 40 & 4 & 62 \\
\hline Молдова & 40 & 14 & 50 \\
\hline Білорусія & 33 & 22 & 49 \\
\hline Австрія & 37 & 2 & 61 \\
\hline Португалія & 43 & 3 & 63 \\
\hline Польща & 26 & 7 & 73 \\
\hline
\end{tabular}

Джерело: складено автором за даними [9]

Отже, можна стверджувати про певні закономірності в розподілі складових національного багатства, на основі чого і варто будувати стратегію розвитку нашої держави. А саме, беручи приклад з високорозвинених країн, Україні варто робити інвестиції саме в людський капітал, який $\epsilon$ основою для такого нематеріального нагромадження. Адже саме інвестиції в зростання людського капіталу гарантують подальший економічний розвиток для країни.

Висновки та перспективи подальших досліджень. Отже, національне багатство $є$ одним із важливих індикаторів стану розвитку економіки. Це сукупність створених і накопичених в країні працею всього суспільства матеріальних благ, рівня освіти, виробничого досвіду, майстерності, творчого обдарування населення за всю його історію.

На сьогоднішній день в Україні відсутня методологія вартісних оцінок та системних досліджень національного багатства України. Така методологія дала би змогу здійснити оцінку реальних втрат національного багатства України в результаті анексії Криму та формування непідконтрольних територій в результаті військових дій на сході України, що може бути напрямком подальшого дослідження.

Якісний та системний аналіз дослідження національного багатства України необхідний з метою окреслення напрямів підвищення ефективності його використання. Визначення складу й стану національного багатства країни дозволяє виявити основні пріоритети розвитку, а саме: формувати й коригувати структурну політику, політику приватизації, інвестиційну політику тощо.

За результатами аналізу можна зробити висновок, що в Україні пріоритетним напрямком зростання національного багатства - це інвестиції саме в людський капітал.

\section{Джерела та література}

1. Ляховець О.О.Оцінка національного багатства України. Економіка. Наукові праці. 2009.Том 126.Випуск 113. С.5-10.

2. Бобух I.M. Оцінка національного багатства у контексті міжнародного досвіду. Економіка i прогнозування. 2011. № 10. С.24-39.

3. Квак М. В. Національне багатство в системі формування екологічно збалансованого розвитку економіки України. Актуальні проблеми розвитку економіки регіону. 2008. Вип. IV, Т.2. С. 257-264.

4. Шумська С.С.Національне багатство України у вимірі показників СНР. Фінанси України. 2012. №4. C.27-40.

5. Степаненко С.В. Підвищення ефективності процесів суспільного відтворення та використання національного багатства. Теорія та практика державного управління. 2013. Вип. 3 (42). С.81-88.

6. Економічна оцінка природного багатства України : [монографія] /[Хвесик М. А. та ін.] ; за заг. ред. Пирожкова С. І., Хвесика М. А. ; НАН України, Держ. установа «Ін-т економіки природокористування та сталого розвитку НАН України».Київ :ДУ ІЕПСР НАН України, 2015. 395с.

7. The World Bank. The Changing Wealth of Nations. URL:

http://www.documents.worldbank.org/curated/en/630181468339656734/ (дата звернення: 21.12.2019).

8. База даних державної служби статистики України: веб-сайт. ULR: http://www.ukrstat.gov.ua/ (дата звернення: 21.12.2019). 
9. The Changing Wealth Of Nations 2018. International Bank for Reconstruction and Development . The World Bank. URL: http://www.worldbank.org (дата звернення: 21.12.2019).

10. Руденко В. М. Математична статистика. Навч. посіб. Київ: Центр учбової літератури, 2012. 304 с.

\section{References}

1. Lyachovets O.O. (2009) Otsinka natsionalnogo bagatstva Ukrainy. [Assessment of Ukraine's national wealth]. Ekonomika - Economy. Scientific works. Vol. 126.Vyp. 113, 5-10 [in Ukrainian].

2. Bobukh I.M.(2011) Otsinka natsionalnogo baghatstva u konteksti mizhnarodnogo dosvidu. [Assessment of national wealth in the context of international experience]. Ekonomika $\mathrm{i}$ prognozuvannya - Economics and forecasting, 10, 24-39 [in Ukrainian].

3. Kvak M.V.(2008) Natsionalne bagatstvo v systemi formuvannya ekologhichno zbalansovanogo rozvytku ekonomiky Ukrayiny.[ National wealth in the system of formation of ecologically balanced development of economy of Ukraine]. Aktualni problem rozvytku ekonomiky region - Actual problems of regional economy development. Vyp. IV, T.2, 257-264 [in Ukrainian].

4. Shumska S.S.( 2012.) Natsionalne bagatstvo Ukrainy u vymiri pokaznykiv SNR. [Ukraine's national wealth in measuring SNA indicators.] Finansy Ukrainy - Finance of Ukraine.4, 27-40 [in Ukrainian].

5. Stepanenko S.V. Pidvyshennya efektyvnosti protsesiv suspilnogo vidtvorennya ta vykorystannya natsionalnogo bagatstva. [Increasing the efficiency of the processes of social reproduction and use of national wealth.] Teoriya ta praktyka derzhavnogo upravlinnya - Public administration theory and practice. Vyp. 3 (42), 81-88 [in Ukrainian].

6. Pyrozhkova S. I., Khvesyk M. A. (Eds.), (2015). Ekonomichna ocinka pryrodnogho baghatstva Ukrajiny [Economic valuation of Ukraine's natural wealth]. Kyjiv: DU IEPSR NAN of Ukraine, 395 [in Ukrainian].

7. The World Bank. The Changing Wealth of Nations. Retrieved from: http://www.documents.worldbank.org/curated/en/630181468339656734/

8. Database of the State Statistics Service of Ukraine. Retrieved from: http://www.ukrstat.gov.ua/

9. The Changing Wealth Of Nations (2018) .International Bank for Reconstruction an Development . The World Bank. Retrieved from:http://www.worldbank.org

10. Rudenko V.M.(2012) Matematychna statystyka [Mathematical statistics] Tutorial. Kyiv: Tsentr uchbovoyi literatury, 304 [in Ukrainian].

Стаття надійшла до редакції 17.01.2020 p. 